International Research Journal of Management, IT \& Social Sciences
Available online at https://sloap.org/journals/index.php/irjmis/
Vol. 9 No. 1, January 2022, pages: 131-137
ISSN: 2395-7492
https://doi.org/10.21744/irjmis.v9n1.2019

\title{
Impact of US Dollar Exchange Rate and Inflation on Profitability
}

CrossMark

Andri Azmi ${ }^{a}$

Mohamad Adam ${ }^{\text {b }}$

Marlina Widiyanti ${ }^{\mathrm{c}}$

Shelfi Malinda ${ }^{\mathrm{d}}$

Article history:

Submitted: 09 October 2021

Revised: 18 November 2021

Accepted: 27 December 2021

\section{Keywords:}

dollar exchange;

inflation;

profitability;

rate;

Return on Assets (ROA);

Corresponding author:

Andri Azmi,

Master of Management, Sriwijaya University, Palembang, Indonesia

Email address: andriazmi.aa@gmail.com

\begin{abstract}
This study aims to examine the significance of the effect of the dollar exchange rate and inflation on the profitability of PT. Pupuk Sriwidjaja Palembang. Profitability in this study is measured by return on assets (ROA) with the research period from 2014-2020. The data analysis technique for testing the hypothesis in this study used multiple linear regression. The study results concluded that the dollar exchange rate and inflation had a significant positive effect on the profitability (ROA) of PT. Pupuk Sriwidjaja Palembang during 2014-2020. This result contradicts the proposed hypothesis 2 and the theory proposed previously. The positive effect is possible that because the inflation rate is not too high, the company takes advantage of the gap.
\end{abstract}

International research journal of management, IT and social sciences (C) 2022. This is an open access article under the CC BY-NC-ND license (https://creativecommons.org/licenses/by-nc-nd/4.0/).

a Sriwijaya University, Palembang, Indonesia

${ }^{\mathrm{b}}$ Sriwijaya University, Palembang, Indonesia

Sriwijaya University, Palembang, Indonesia

Sriwijaya University, Palembang, Indonesia 


\section{Introduction}

In the last few years, the condition of the fertilizer industry with the main product in the form of urea has faced considerable challenges, whereas globally, urea production has experienced an oversupply. Another challenge faced by the fertilizer industry in Indonesia is the government's high price of natural gas, which does not follow the changes in world natural gas prices. The Government of Indonesia determines the price of natural gas by referring to the Regulation of the Minister of Energy and Mineral Resources No. 40 of 2016, which has been in effect since January 1, 2017, where gas tariffs for specific industries, including the Fertilizer Industry are determined based on a formula set by the government, namely US\$ 6 per MMBtu. This dramatically affects the ability of fertilizer companies to compete in local and global markets.

Pupuk Sriwidjaja Palembang, as a company in the government-owned fertilizer industry, is indeed very supportive of the condition of the global fertilizer industry because, in addition to Pusri's obligation to fulfill fertilizer needs for farmers, which is an assignment from the government, Pusri is also a profit company that must seek optimal profits. Pusri has made various efforts to compete, especially with local competitors, which are similar companies under Pupuk Indonesia Holding Company, to produce company performance that can be seen from the level of profitability. According to Coppeland \& Weston (1992), profitability is an essential prerequisite for maintaining the long-term sustainability of a company and has a significant effect on the company's financial performance.

In the last five years, Pusri has faced quite severe conditions where the company's profitability based on the ROA ratio is relatively low and tends to decline (Rostami et al., 2016; Miyazato, 2010). This ratio is essential for management to evaluate the effectiveness and efficiency of company management in managing all company assets (Widiyanti \& Elfina, 2015). Low and declining profitability can be caused by various things, both from internal and external factors of the company. External factors that influence and will also be independent variables in this study are the dollar exchange rate and inflation (Kim, 2003; Frenkel et al., 2005).

Pusri conducts transactions using rupiah and US dollars to carry out its business processes. The US dollar currency is mainly used to pay the cost of natural gas as a raw material, where about $70 \%$ of the production cost is from the cost of natural gas. Therefore, it is estimated that the US dollar exchange rate will affect Pusri's financial performance in terms of profitability (Sugosha \& Artini, 2020).

Sales of commercial urea products with relatively fixed raw material costs with natural gas price regulations determined by the government is challenging for Pusri. Pusri will continue to produce at the exact cost when economic conditions change, resulting in changes in the company's performance. For example, the inflation rate increases or decreases which will undoubtedly impact changes in people's purchasing power, but the production cost of commercial urea produced by Pusri remains relatively unchanged (Gonçalves \& Salles, 2008; Bruno \& Easterly, 1998).

Several previous studies concluded different results on how the dollar exchange rate and inflation affect profitability. For example, studies that state that the exchange rate harms profitability are research Zein et al. (2020), Sasmita et al. (2019), Hasanov et al. (2018), Amenawo et al. (2016). On the other hand, research conducted by Sari \& Baskara (2018), states that the exchange rate has a positive effect on profitability. Another result was stated by research Rizwan et al. (2020), Dewi et al. (2019), Tumewang et al. (2020), Prastowo et al., (2018), Pamungkas \& Suhadak (2017), Karamollaoglu (2017), Adiyadnya et al. (2016), Osundina et al. (2016), which stated that the exchange rate had no effect to profitability.

Previous research that concluded that inflation harmed profitability was researched Zein et al. (2020), Egbunike \& Okerekeoti (2018). It is advisable to conclude that inflation has a positive effect on research Hasanov et al. (2018), Sari \& Baskara (2018). Research Suzulia \& Saluy (2020), Rachmawati \& Marwansyah (2019), Adyatmika \& Wiksuana, (2018), Ifeanyi \& Chukwuma (2016), conclude that inflation does not affect company profitability. Based on the phenomena regarding the exchange rate and inflation and how they affect its profitability (Alsyouf, 2007; Pasiouras \& Kosmidou, 2007). The differences in the results of previous studies are the basis for this research.

\section{Materials and Methods}

The type of data used in this research is secondary data. The source of profitability data is taken from the monthly financial statements of PT. Pupuk Sriwidjaja Palembang during the period from 2014 to 2020. The dollar exchange data was taken from the website of Bank Indonesia (BI) and inflation data from the Central Statistics Agency (BPS). The dependent variable in this study is profitability as measured by return on assets (Sari \& Sedana, 2020). The independent variables in this study are the dollar exchange rate against the rupiah, which is the middle UKA 
exchange rate at the end of each month taken, and the inflation variable is measured from changes in the Consumer Price Index (Deeds \& Hill, 1996; Puyravaud, 2003).

This study uses multiple linear regression as a data analysis technique or as a model for erratic movement projection. Descriptive statistics, model feasibility test (F test), and individual significance test (t-test) were also used as hypothesis testing. This study transforms the data into Lag form due to the emergence of classical assumption problems in the data, the equation that will be used is as follows:

$$
\text { Lag_ROA }=\beta 0+\beta 1 \text { Lag_Kurs }+\beta 2 \text { Lag_Inflasi }+e_{i}
$$

\section{Results and Discussions}

Descriptive analysis results

Ferdinand (2014), explains that descriptive analysis aims to share illustrations of the information presented in studies. The descriptive analysis contains information about the highest data (maximum), the lowest data (minimum), the average data (mean), and the standard deviation of the data or the standard error.

Table 1

Descriptive statistics

\begin{tabular}{lccccc}
\hline Variable & $\mathrm{N}$ & Minimum & Maximum & Mean & Std. Deviasi \\
\hline Kurs Dollar (Rp) & & 11427,05 & 15867,43 & 13559,15 & 921,3361 \\
Inflasi (\%) & 60 & $-0,45$ & 2,46 & 0,3 & 0,41 \\
ROA (\%) & & $-0,11$ & 4,03 & 1,04 & 0,76 \\
\hline
\end{tabular}

Source: SPSS output (processed data)

Table 1 above provides information on each variable. In the table, it can be seen that only the inflation variable has an average value (mean) that is smaller than the standard deviation, indicating that the distribution of data from inflation is not good or not centered on the average.

F-Test (F Test)

The model feasibility test or F test is used to see the independent variables' effect on the dependent variable. The effect of presence or absence is based on the output of the ANOVA table (analysis of variance) if the calculated F value is greater than the table F value and the Sig value. More petite than 0.05 (significance level), which is determined, the independent variables affect the dependent variable (Ghozali, 2018).

Table 2

F-Test Results

\begin{tabular}{lc}
\hline Mark & Coefficient \\
\hline F $_{\text {count }}$ & 13,477 \\
F $_{\text {table }}$ & 3.11 \\
Sig & 0.000 \\
\hline
\end{tabular}

Source: SPSS output (processed data)

The table above shows that the calculated $\mathrm{F}$ value is 13,477 , which is greater than the table $\mathrm{F}$ value, which is only 3.11 . The value of Sig. in the table above also shows a value smaller than 0.05 or $5 \%$. In conclusion, the dollar exchange rate and inflation variables together have a significant effect on profitability (ROA).

Azmi, A., Adam, M., Widiyanti, M., \& Malinda, S. (2022). Impact of US dollar exchange rate and inflation on profitability. International Research Journal of Management, IT and Social Sciences, 9(1), 131-137. 
Individual parameter significance test (t-Test)

The individual parameter significant test or test is a test that shows the influence of each variable individually on the dependent variable (Ghozali, 2011). The basis for deciding whether the effect of the variable is the same as the F test is if the t-count value is greater than the t-table value and the Sig value. If smaller than 0.05 (significance level), determined then the variable affects the dependent.

Table 3

Significance test results

\begin{tabular}{|c|c|c|c|c|c|}
\hline \multirow{2}{*}{ Model } & \multicolumn{2}{|c|}{ Unstandardized Coefficients } & \multirow{2}{*}{$\begin{array}{c}\text { Standardized } \\
\text { Coefficients } \\
\text { Beta }\end{array}$} & \multirow{2}{*}{$\mathrm{t}$} & \multirow{2}{*}{ Sig. } \\
\hline & $\mathrm{B}$ & Std. Error & & & \\
\hline (Constant) & $-1,563$ & 0.940 & & $-1,663$ & 0.100 \\
\hline Rate_Lag & 0.000267 & 0.000124 & 0.209 & 2,147 & 0.035 \\
\hline Lag_Inflation & 0.864 & 0.175 & 0.481 & 4,942 & 0.000 \\
\hline
\end{tabular}

Source: SPSS output (processed data)

Based on the table above, multiple linear regression equations can be made as follows:

$$
\text { Lag_ROA }=-1.563+0.000267 \text { Exchange_Lag }+0.864 \text { Inflation Lag }
$$

The following is a description of the results of the t-test above and the regression equation above:

a) In the above equation, the first value is constant. The constant itself is a value that does not change in the equation. This value is the value of the $\mathrm{Y}$ variable or the dependent variable. If the independent variable is zero, then the ROA value is -1.563 .

b) The value of 0.000267 in the equation is the sensitivity value of the exchange rate variable or exchange rate. The positive value indicates that an increase in the exchange rate or the exchange rate is depreciating against the US Dollar (USD), so the ROA value also increases. Suppose the exchange rate increases by $1 \%$ or one unit, the amount of change will increase ROA by $0.000267 \%$. The exchange rate variable based on the table above has a sig value below 0.05 which is 0.035 . The calculated $t$ value also shows a more excellent value than the $t$ table value $(2.147>1.98)$. The beta value of the unstandardized coefficients column shows a positive number, namely 0.000267, indicating a positive direction of influence. Based on the two statements of decision-making, it can be concluded that the exchange rate variable has a significant positive effect on profitability (ROA). This result is not following hypothesis 1 , which was previously proposed, which states the negative effect of the exchange rate variable on profitability (ROA).

c) The inflation variable also shows a positive sensitivity of 0.846 . A positive value indicates that an increase in inflation also affects ROA in the same direction. Based on the increase in inflation of $1 \%$ or one unit, it will increase ROA by $0.846 \%$. The inflation variable in the table above is known to have an at-count value more significant than the t-table value, namely $4.942>1.98$. The value of sig. from the table above has a smaller value than the specified significance level $(0.000<0.05)$. Based on these two statements, it is found that inflation has a significant effect on profitability (ROA), but the direction shown is positively seen from the value of the unstandardized coefficients column. This result does not match or contradict hypothesis 2 proposed earlier, which states that inflation should hurt company profitability.

\section{The effect of dollar exchange rate on profitability (ROA)}

This study concludes that the dollar exchange rate has a significant positive effect on the profitability (ROA) of PT. Pupuk Sriwidjaja Palembang period 2014-2020. The results show that an increase in the dollar exchange rate will increase the company's ROA value in the same direction. An increase in the value of the US Dollar exchange rate or appreciation of the rupiah will increase profitability at the company PT. Pupuk Sriwidjaja Palembang. Conversely, if the US Dollar has decreased or depreciated, the profitability (ROA) of PT. Pupuk Sriwidjaja Palembang also declined. This result. When the value of the US Dollar increases or appreciates against the rupiah, all transactions involving the 
US Dollar will be disrupted. Companies whose orientation is to import or import raw materials more than exports will be disturbed, and some exporting companies will benefit from this situation. This result is not following hypothesis 1 stated in the previous chapter 2 and the theory that has been described. Several similar studies which show that the dollar exchange rate has a positive effect on profitability are Sari \& Baskara (2018).

\section{Effect of inflation on profitability (ROA)}

The study results concluded that the inflation variable had a significant positive effect on the profitability (ROA) of PT. Pupuk Sriwidjaja Palembang period 2014-2020. These results also indicate that the increase in inflation that occurs will increase the profitability of PT. Pupuk Sriwidjaja Palembang. This study shows a positive correlation of inflation where the higher inflation will result in the profitability (ROA) of PT. Pupuk Sriwidjaja Palembang is also getting higher.

This result contradicts the proposed hypothesis 2 and the theory proposed previously. The positive effect is possible that because the inflation rate is not too high, the company takes advantage of the gap. An increase in the value of prices that is higher than the increase in the fundamental value of the principal subject to inflation can also cause a positive impact on the company. Based on the previous descriptive statistical analysis, it is known that the average inflation rate is only $0.3 \%$.

When the price of goods rises not too sharply due to inflation, producers of goods such as staples will benefit. Fertilizer demand may also increase as essential commodity producers are encouraged to increase production. This increase will increase profits for fertilizer companies so that profitability, as measured by profit, will also increase. This statement is a possibility that occurs if the inflation rate is low with a higher income level than the increase in the cost of producing goods. The results of this study are in line with the results of research from Hasanov et al. (2018), Sari \& Baskara (2018). Their research shows that inflation has a positive and significant effect on company profitability.

\section{Conclusion}

This study concludes that the dollar exchange rate and inflation have a significant positive effect on the profitability (ROA) of PT. Pupuk Sriwidjaja Palembang period 2014-2020.

\section{Conflict of interest statement}

The authors declared that they have no competing interests.

\section{Statement of authorship}

The authors have a responsibility for the conception and design of the study. The authors have approved the final article.

\section{Acknowledgments}

All creators offer special thanks for every one of the commitments we have gotten, both from the start as brilliant thoughts and just as financing help from the public authority, for this situation the service of training and culture. We accept that without the subsequent help, we can not deliver protein on schedule.

Azmi, A., Adam, M., Widiyanti, M., \& Malinda, S. (2022). Impact of US dollar exchange rate and inflation on profitability. International Research Journal of Management, IT and Social Sciences, 9(1), 131-137. 


\section{References}

Adiyadnya, I. N. S., Artini, L. G. S., \& Rahyuda, H. (2016). Pengaruh Beberapa Variabel Ekonomi Makro Terhadap Profitabilitas dan Return Saham Pada Industri Perbankan di BEI. E-Jurnal Ekonomi dan Bisnis Universitas Udayana, 5(8), 2601-2602.

Adyatmika, I. G. P., \& Wiksuana, I. G. B. (2018). Pengaruh Inflasi Dan Leverage Terhadap Profitabilitas Dan Return Saham Pada Perusahaan Manufaktur Di Bursa Efek Indonesia. E-Jurnal Ekonomi Dan Bisnis Universitas Udayana, 3(7), 615-648.

Alsyouf, I. (2007). The role of maintenance in improving companies' productivity and profitability. International Journal of production economics, 105(1), 70-78. https://doi.org/10.1016/j.ijpe.2004.06.057

Amenawo, I., Riman, H. B., \& Akpan, E. S. (2016). Foreign exchange fluctuations and commercial banks profitability in Nigeria. Foreign exchange, 7(18).

Bruno, M., \& Easterly, W. (1998). Inflation crises and long-run growth. Journal of Monetary economics, 41(1), 3-26. https://doi.org/10.1016/S0304-3932(97)00063-9

C Nnado, I., C, U.C., 2016. An Empirical Analysis of Inflationary Impacts on Profitability and Value of Selected Manufacturing Firms in Nigeria. Res. J. Finance Account. 7, 19-26.

Coppeland, T.E., \& Weston, J.F. (1992). Financial Theory And Corporate Policy, 5th ed. Addison-Wesley Publishing Company, USA.

Deeds, D. L., \& Hill, C. W. (1996). Strategic alliances and the rate of new product development: An empirical study of entrepreneurial biotechnology firms. Journal of business venturing, 11(1), 41-55. https://doi.org/10.1016/08839026(95)00087-9

Dewi, V. I., Tan Lian Soei, C., \& Surjoko, F. O. (2019). The Impact of Macroeconomic Factors on Firms Profitability (Evidence From Fast Moving Consumer Good Firms Listed on Indonesian Stock Exchange).

Egbunike, C. F., \& Okerekeoti, C. U. (2018). Macroeconomic factors, firm characteristics and financial performance: A study of selected quoted manufacturing firms in Nigeria. Asian Journal of Accounting Research.

Ferdinand, A. (2014). Metode Penelitian Manajemen: Pedoman Penelitian untuk Penulisan Skripsi Tesis dan Desrtasi Ilmu Manajemen.

Frenkel, M., Pierdzioch, C., \& Stadtmann, G. (2005). The effects of Japanese foreign exchange market interventions on the yen/US dollar exchange rate volatility. International Review of Economics \& Finance, 14(1), 27-39. https://doi.org/10.1016/j.iref.2003.09.003

Ghozali, I. (2011). Aplikasi Analisis Multivariate Program IBM SPSS 19. Badan Penerbit UNDIP: Semarang.

Ghozali, I. (2018). Aplikasi analisis multivariate dengan program IBM SPSS 25.

Gonçalves, C. E. S., \& Salles, J. M. (2008). Inflation targeting in emerging economies: What do the data say?. Journal of Development Economics, 85(1-2), 312-318. https://doi.org/10.1016/j.jdeveco.2006.07.002

Hasanov, F. J., Bayramli, N., \& Al-Musehel, N. (2018). Bank-specific and macroeconomic determinants of bank profitability: Evidence from an oil-dependent economy. International Journal of Financial Studies, 6(3), 78.

Ifeanyi, N., \& Chukwuma, U. (2016). An Empirical Analysis of Inflationary Impacts on Profitability and Value of Selected Manufacturing Firms in Nigeria. Research Journal of Finance and Accounting Vol, 7, 19-26.

Karamollaoğlu, N. (2017). Effects of exchange rates on corporate profits: a TOBIT analysis. Yönetim ve Ekonomi Araştırmaları Dergisi, 15(1), 15-26.

Kim, K. H. (2003). Dollar exchange rate and stock price: evidence from multivariate cointegration and error correction model. Review of Financial economics, 12(3), 301-313. https://doi.org/10.1016/S1058-3300(03)00026-0

Miyazato, N. (2010). The optimal size of Japan's public pensions: An analysis considering the risks of longevity and volatility of return on assets. Japan and the World Economy, 22(1), 31-39. https://doi.org/10.1016/j.japwor.2009.06.001

Osundina, C. K., Osundina, J. A., Jayeoba, O. O., \& Olayinka, I. M. (2016). Exchange rate volatility and banks performance: Evidence from Nigeria. International Journal of Economics and Business Management, 2(4), 1-11.

Pamungkas, D. P., \& Suhadak, S. (2017). The Effect of Jet Fuel Price and Macroeconomics Variables on Profitability of Airline Industry in Asia (Study at Airline Companies in Indonesia, India, and China Period 2006-2015). Jurnal Administrasi Bisnis, 50(3), 208-217.

Pasiouras, F., \& Kosmidou, K. (2007). Factors influencing the profitability of domestic and foreign commercial banks in the European Union. Research in International Business and Finance, 21(2), 222-237. https://doi.org/10.1016/j.ribaf.2006.03.007

Prastowo, P. R., Mardani, R. M., \& Wahono, B. (2018). Analisis Pengaruh Inflasi, Suku Bunga dan Nilai Tukar Terhadap Profitabilitas Perbankan. Jurnal Ilmiah Riset Manajemen, 7(16). 
Puyravaud, J. P. (2003). Standardizing the calculation of the annual rate of deforestation. Forest ecology and management, 177(1-3), 593-596. https://doi.org/10.1016/S0378-1127(02)00335-3

Rachmawati, S., \& Marwansyah, S. (2019). Pengaruh Inflasi, Bi Rate, Car, Npl, Bopo Terhadap Profitabilitas Pada Bank Bumn. Jurnal Mantik, 3(1), 117-122.

Rizwan, E. K., Rizwan, A. P., Rizwan, W. S., Rizwan, D. A. P., \& Rizwan, A. R. (2020). The Determinant Factors Of Profitability In Indonesia Consumer Goods Manufacturing Companies. PalArch's Journal of Archaeology of Egypt/Egyptology, 17(10), 3759-3772.

Rostami, S., Rostami, Z., \& Kohansal, S. (2016). The effect of corporate governance components on return on assets and stock return of companies listed in Tehran stock exchange. Procedia Economics and Finance, 36, 137-146. https://doi.org/10.1016/S2212-5671(16)30025-9

Sari, I. A. G. D. M., \& Sedana, I. B. P. (2020). Profitability and liquidity on firm value and capital structure as intervening variable. International Research Journal of Management, IT and Social Sciences, 7(1), 116-127. https://doi.org/10.21744/irjmis.v7n1.828

Sari, N. P. E., \& Baskara, I. G. K. (2018). Nilai Tukar, Nilai Ekspor, Dan Pertumbuhan Ekonomi Terhadap Profitabilitas Eksportir Food and Beverage Di Bei. E-Jurnal Manajemen Unud, 7(8), 4181-4210.

Sasmita, D., Andriani, S., \& Ilman, A. H. (2018). Analisis Pengaruh Inflasi, Suku Bunga Bi, Nilai Tukar Rupiah Terhadap Profitabilitas (Studi Kasus Pada Bank Yang Terdaftar Di Bei Periode 2011-2015). Jurnal Ekonomi Dan Bisnis Indonesia, 3(1).

Sugosha, M. J., \& Artini, L. G. S. (2020). The role of profitability in mediating company ownership structure and size of firm value in the pharmaceutical industry on the Indonesia stock exchange. International Research Journal of Management, IT and Social Sciences, 7(1), 104-115. https://doi.org/10.21744/irjmis.v7n1.827

Suzulia, M. T., \& Saluy, A. B. (2020). The Effect Of Capital Structure, Company Growth, And Inflation On Firm Value With Profitability As Intervening Variable (Study On Manufacturing Companies Listed On Bei Period 20142018). Dinasti International Journal of Economics, Finance \& Accounting, 1(1), 95-109.

Tumewang, Y. K., Isnaini, R. N., \& Musta'in, J. L. (2020). The impact of macro economy toward profitability of Islamic bank. Asian Journal of Islamic Management, 1(2), 101-108.

Widiyanti, M., \& Elfina, F. D. (2015). Pengaruh financial leverage terhadap profitabilitas pada perusahaan sub sektor otomotif dan komponen yang terdaftar di Bursa Efek Indonesia. Jurnal Manajemen dan Bisnis Sriwijaya, 13(1), 117-136.

Zein, R. A., Ali, M., \& sari Dewi, A. R. (2020). Study of Factors Affecting the Profitability and Firm Value of LQ45. Hasanuddin Journal of Applied Business and Entrepreneurship, 3(3), 50-67.

Azmi, A., Adam, M., Widiyanti, M., \& Malinda, S. (2022). Impact of US dollar exchange rate and inflation on profitability. International Research Journal of Management, IT and Social Sciences, 9(1), 131-137. 